ducts, with their columnar epithelium unchanged, multiplied 100 diameters. The lower figure represents a part of the new growth shewing a mass of cells and nuclei of elongated form, constituting a cord-like body, like those seen under the skin, multiplied Iooo diameters; and a part of the new growth multiplied 1000 diameters, shewing cells imbedded in a trabecular work of fibres.

FIG. 6.- A small nodule from the omentum of the guinea-pig, seated at the bifurcation of a small artery. In the denser part around the artery little is to be seen but a closely packed mass of nuclei. The nuclei lie imbedded in the broad bands of fibrillated tissue, of which the

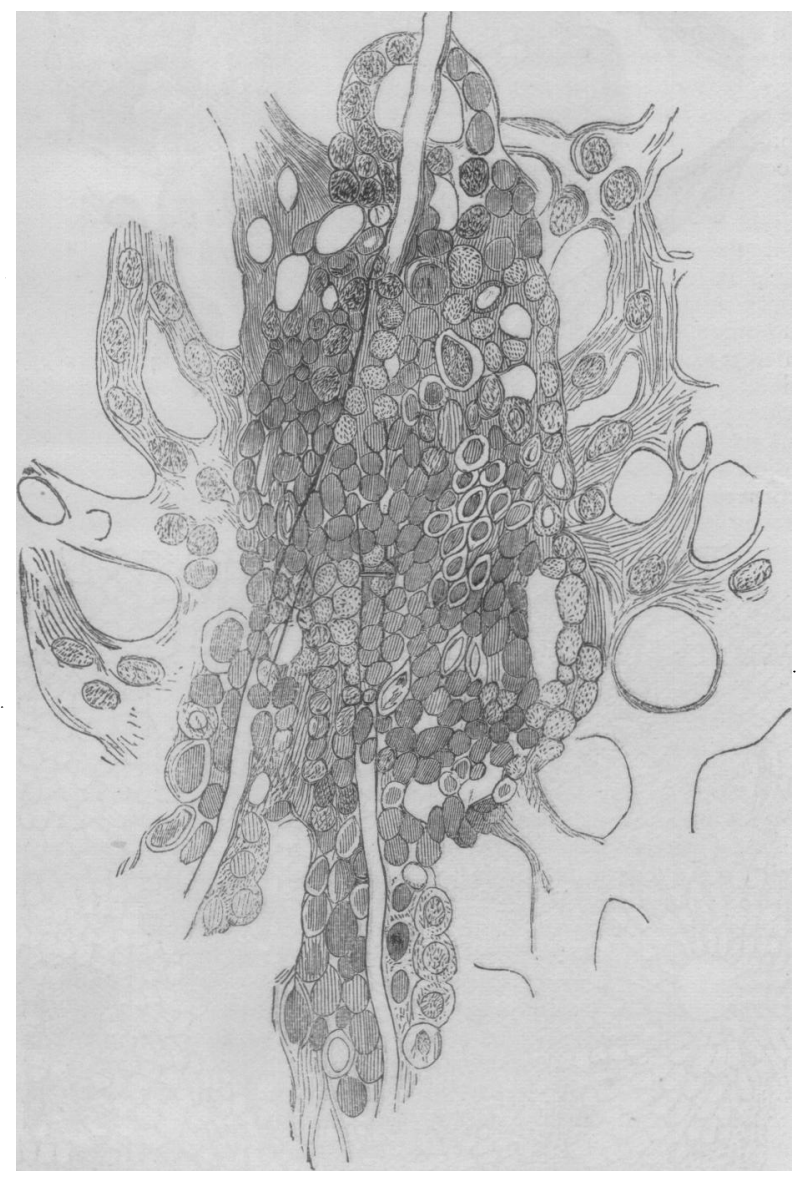

Fig. 6

omentum is composed. Even in the denser parts a reticular arrangement of the growth is thus preserved, but the open spaces are diminished in size. At a greater distance, the growth is still seen to originate from the same nuclei, which lie in rows imbedded in the fibres. In some places, an outer cell-wall around the nuclei is visible, the cells being large and round. Multiplied rooo diameters.

ERRATUm. In last number of Journal, May 30, p. 526, second column, sixth line, instead of "what is ordinarily considered not tubercle," read "what is ordinarily considered to be tubercle."

Alcohol in the Treatment of Pnecironia.-M. Pécholier, in a work lately published by him on this subject, expresses his opinion as follows: "We hold it to be demonstrated, by facts and arguments, that the beneficial action of alcohol in certain kinds of inflammation, and specially in certain kinds of pneumonia, is, in the first instance, due to the stimulating action of this agent. We, therefore, accept a portion of Todd's theories, without falling into his exclusiveness. If, in all cases of pneumonia, the vital powers are not always greatly weakened, as the English physician asserts, there exists a kind of pneumonia in which the radical forces are destroyed, and in which curative reaction requires to be stimulated. For this kind of pneumonia, Dr. Todd's prescription is proper; in others, it is useless, and sometimes even injurious."

\section{CONTRIBUTIONS TO THE HISTORY OF MEDICINE.}

By AQUILLA SMITH, M.D.,

Professor of Materia Medica and Pharmacy in Trinity College, Dublin.

I.-ON the Treatment of Coryza, or NASAl Catarrh, by "A TOTAL ABStinenCE From LiQUid."

Dr. Charles J. B. Williams, in the article "Coryza" published in the Cyclonadia of Practical Medicine in 1833, after giving the usual treatment by aperients, diaphoretics, and diluents, adds: "It is the acrimony of this discharge (from the pituitary membrane) which reacts on the membrane and keeps up the inflammation and its accompanying disagreeable symptoms. On this circumstance depends the efficacy of a measure directly opposed to that just noticed, but to the success of which we can bear decided testimony-we mean a total abstinence from liquids." "This method of cure operates by diminishing the mass of fluid in the body to such a degree that it will no longer supply the diseased secretion." "The coryza begins to be dried $\iota p$ about twelve hours after leaving off liquids; from that time the flowing to the eyes and fulness in the head become less and less troublesome; the secretion becomes gelatinous, and between the thirtieth and thirty-sixth hour ceases altogether. The whole period of abstinence needs scarcely ever to exceed forty-eight hours."

Assuming that priority of publication of opinions or experiments is justly entitled to the merit of originality, and without any intention of detracting from Dr. Williams's acknowledged reputation, I proceed to show that, in his method of treating coryza, he was anticipated by an eminent English physician at the close of the seventeenth century.

The author, in Tractatus de Corde, cui accessit Dissertatio de Origine Catarrhi, in qua ostenditur illum non provenire a Cerehro, authori Richardo Lower, M.D., editio tertia et ultima, Amstelodami I67I, in cap. vi, De Catarrhis, says: "Cùm vero catarrhi materia, occasio atque organcrum in eo secernendo ministeria ex præmissis constiterint; satis obvium et facile erit concipere quod illi sistendo aptissimè conferet..... In quantum igitur ex sero sanguinis materia catarrho suppeditatur, quicquid ei pabulum detrahit, aut serum per renes præcipiat, vel per alvum derivat, vel per poros corporis dispellit, intentioni curativæ apprimè satisfacit. Quare quum catarrhus primo urget, nihil majus ei supprimendo conducit, modo absque febre sit, quam ut sitim diutissimè toleremus; tridui enim vel quatridui abstinentia d potu plures novi à catarrho prorsus liberatos, cujus alia ratio non est, quàm quod fomite subducto orinino exsiccatur, non aliter ac rivuli exarescunt ex pluviarum penuriâ." (P. 234.)

In the extracts from Dr. Williams's article on Coryza, the words in italics are his own; and in the quotation from Lower $I$ have put a few words in italics to shew the parallelism.

\section{ON IODIDE OF METHYLE AND THERAPEUTICAL RESEARCHES.}

\section{By JAMES TURNBULL, M.D., Liverpool.}

I OBSERVE in the BRITISH MEDICAL JoURNal of April r8th, a report of a meeting of the Medical Society of London, at which Dr. B. W. Richardson presided and exhibited a specimen of iodide of methyle, which, he thought, promised to prove of the greatest use in practical medicine. He also made the statement that the iodide was first experimented with physiologically by himself last year, and was reported on by him to the meeting of the British Association at Dundee. It is proper that I should correct this statement and the error into which Dr. Richardson has unwittingly fallen ;* for if there be any merit in being the first to investigate the physiological properties of this and other allied compounds, I ought to assert my claim to it, having read a paper, at the meeting of the British Association for the Advancement of Science held at Liverpool in I854, entitled "Researches on the Physiological and Medicinal Properties of some of the compounds of the Organic RadicalsMethyle, Ethyle, and Amyle." The paper was afterwards published in the Association Medical Journal, where, in the volume for I865, page 69 , the following account of the properties of iodide of methyle is given.

" Iodide of Methyle. - The next compound of methyle, the iodide, is a

* April 22nd, r868. Since this was written and sent to the Editor of the JourNal, Dr. Richardson has in the most handsome manner rectified this mistake by a statement made at tbo subsequent meeting of the Medical Society of London. - J. T. 